\title{
PENGARUH KULIAH ONLINE TERHADAP MOTIVASI BELAJAR MAHASISWA DI DAERAH JABODETABEK SELAMA MASA PANDEMIK COVID-19
}

\author{
Melkianus Albin Tabun \\ (Universitas Pelita Harapan) \\ (e-mail: tabunmelkianus@gmail.com)
}

\begin{abstract}
Abstrak
Penelitian ini bertujuan untuk mengetahui apakah kuliah online berpengaruh positif dan signifikan terhadap motivasi belajar mahasiswa pada perguruan tinggi di daerah Jabodetabek (Jakarta-Bogor-Depok-Tangerang-Bekasi) selama masa pandemik covid-19. Pengumpulan data menggunakan angket berupa google form yang disebarkan kepada 200 responden. Metode analisis data yang digunakan adalah analisis deskriptif dan analisis regresi linear sederhana. Berdasarkan hasil analisis deskriptif variabel penelitian diperoleh hasil bahwa pada dasarnya kuliah online tidak seefektif dan seefisien kuliah tatap muka, kuliah online di masa pandemik covid-19 ini tidak berjalan seoptimal dan semaksimal kuliah tatap muka. Sedangkan berdasarkan hasil analisis regresi linear sederhana menunjukkan kuliah online berpengaruh positif terhadap motivasi belajar mahasiswa pada perguruan tinggi di daerah Jabodetabek.
\end{abstract}

Kata kunci: Kuliah Online; Motivasi Belajar

Abstract
This study aims to determine whether online lectures have a positive and significant effect on student learning motivation at tertiary institutions in the Greater Jakarta area (Jakarta-Bogor-Depok-Tangerang-Bekasi) during the covid-19 pandemic. Data collection used a questionnaire in the form of google form which was distributed to 200 respondents. The data analysis method used is descriptive analysis and simple linear regression analysis. Based on the results of the descriptive analysis of the research variables, it was found that basically online lectures were not as effective and efficient as face-to-face lectures, online lectures during the Covid-19 pandemic did not run as optimally and as optimally as face-to-face lectures. Meanwhile, based on the results of simple linear regression analysis, online lectures have a positive effect on student learning motivation at tertiary institutions in the Jabodetabek area.

Keywords: Online Learning; Motivation to learn

\section{Pendahuluan}

Saat ini seluruh dunia dilanda oleh pandemik covid-19, termasuk Indonesia. Kehadiran pandemik covid-19 ini membawa dampak transformasi yang sangat signifikan pada setiap sektor usaha, khususnya dalam institusi pendidikan, dimulai dari tingkat kanak-kanak sampai pada tinggkat perguruan tinggi. Metode pembelajaran yang selama ini dilakukan secara konvensional telah beralih menjadi secara modernisasi (e-learning). Konsep pembelajaran yang dikenal dengan istilah $e$-learning ini memberikan dampak transformasi pendidikan dari bentuk konvensional ke dalam bentuk digital, baik dari isi dan sistemnya [1]. Hal ini menunjukkan bahwa pada masa pandemik covid-19 ini, menuntut setiap institusi pendidikan untuk menyesuaikan dengan perkembangan ilmu pengetahuan dan teknologi (IPTEK). Institusi pendidikan yang melek teknologi akan mampu berkompetisi di dunia pendidikan. Sementara institusi pendidikan yang tidak melek teknologi akan tergelincir dengan institusi pendidikan yang melek teknologi. 
Menurut Johnny G Plate, Menteri Komunikasi dan Informatika kepada detiknet bahwa di era industri 4.0 ini, Indonesia membutuhkan talenta digital, namun pada kenyataannya kebutuhan tenaga kerja ahli bidang digital masih belum tercukupi. Hal ini merujuk pada laporan World Bank tahun 2016 mencatat bahwa Indonesia saat ini mengalami kekurangan tenaga kerja semi terampil dan terampil sebesar 9 juta orang dalam 15 tahun. Disamping itu juga bahwa Indonesia saat ini sangat membutuhkan beberapa jenis hard skills untuk menghadapi revolusi industri 4.0, seperti Big Data Analytics, Artificial Intelligence, Cybersecurity, Cloud Computing, Internet of Things, Machine Learning, dan sebagainya. Selain itu juga, harus dilengkapi dengan soft-skill yaitu 21st Century Skills yakni Critical Thinking, Creativity, Collaboration, dan Communication. Hard skills dan soft skills seperti itulah yang paling dibutuhkan untuk akselerasi transformasi digital menuju digital society Indonesia [2].

Agar sistem pembelajaran online dapat berjalan dengan optimal maka setiap institusi pendidikan membutuhkan hard skills dan soft skill seperti yang disebutkan di atas. Namun sayangnya di Indonesia, infrastruktur pada setiap daerah belum merata. Misalnya pada masa pandemik covid-19 ini, setiap institusi pendidikan diharuskan untuk menerapkan sistem pembelajaran online, namun pada kenyataannya beberapa daerah tidak dapat menerapkan sistem tersebut karena adanya berbagai kendala dan keterbatasan fasilitas yaitu tidak ada listrik, tidak ada komputer/ labtop/ gadget, tidak ada jaringan internet, tidak memahami dengan baik tentang penggunaan aplikasi-aplikasi tele konferensi untuk mengadakan kelas online seperti aplikasi Ms. Teams, Zoom, Google Meet, Webex Meet, dan lain sebagainya. Hal ini mengindikasikan bahwa sistem pembelajaran online ini tidak bisa diterapkan pada semua daerah, namun bisa diterapkan pada daerah-daerah yang memadai infrastrukturnya seperti di daerah Jabodetabek (Jakarta-Bogor-Depok-Tangerang-Bekasi) dan beberapa daerah lainnya. Walaupun daerahdaerah tersebut sudah memadai infrastrukturnya, namun proses kegiatan belajar mengajar secara online pada masa pandemik ini masih memerlukan adaptasi yang cukup panjang dari berbagai pihak baik dari guru, dosen maupun peserta didiknya, sebagaimana pernyataan Nadiem Makarim, Menteri Pendididikan dan Kebudayaan bahwa proses adaptasi pembelajaran secara online di masa pandemic covid-19 ini sangat sulit, karena sistem pembelajaran online yang diterapkan ini bukan karena keinginan tetapi karena terpaksa [3]. Artinya bahwa semua institusi pendidikan di Indonesia belum siap untuk menerapkan sistem pembelajaran online. Jika sistem pembelajaran online ini diterapkan karena terpaksa tentunya akan sangat berpengaruh terhadap motivasi belajar peserta didik di Indonesia, khususnya motivasi belajar mahasiswa-mahasiswi di perguruan tinggi.

Ada 3 faktor penting yang mendukung sistem pembelajaran online, diantaranya adalah sumber daya manusia, sarana dan prasana, serta implementasi di lapangan. Jadi kuliah online adalah sistem perkuliahan yang menggunakan akses internet sebagai media pembelajaran yang didesain dalam bentuk modal kuliah, rekaman video, audio atau tulisan oleh pihak universitas. Sedangkan manfaat perkuliahan online adalah (1) mahasiswa dapat mengakses materi perkuliahan dimana saja dan kapan saja tanpa harus bergantung pada jadwal; (2) komunikasi antara dosen dan mahasiswa dapat terjadi setiap saat; (3) melatih mahasiswa untuk dapat belajar secara mandiri dengan memanfaatkan materi kuliah yang diberikan secara online; (4) meningkatkan keterampilan mahasiswa dalam menggunakan komputer beserta perangkat lainnya; (5) melatih mahasiswa untuk terbiasa menggunakan sumber-sumber belajar dari internet; dan (6) dapat mengatasi kekosongan mata kuliah saat dosen berhalangan hadir di kampus [1]. Merujuk pada manfaat kuliah online di atas maka penting bagi setiap perguruan tinggi untuk memperhatikan motivasi belajar mahasiswanya.

Motivasi belajar mahasiswa berkaitan dengan semangat atau gairah yang dimiliki oleh mahasiswa dalam mempelajari setiap bahan yang diberikan oleh dosen, mempunyai semangat yang tinggi untuk mengembangkan diri dalam belajar dan berinisiatif untuk berdiskusi dengan dosen dan teman-teman kuliah. Disamping itu juga, mampu mengaplikasikan setiap ilmu yang diperoleh dari dosen selama mengikuti perkuliahan, sebagaimana pernyataan berikut ini bahwa "motivation to learn reveals that a student desires to take part in, and learn from, a training activity", berarti motivasi berkaitan dengan keinginan mahasiswa untuk mengambil bagian dan 
belajar dari sebuah kegiatan pelatihan [4]. Motivasi belajar adalah dorongan yang menggerakan, mengarahkan, dan mempertahankan perilaku mahasiswa dalam kegiatan belajar statistika, yang timbul dari dalam ataupun dari luar diri mahasiswa, yang tercermin dari kebutuhan, usaha dan ketekunan untuk mencapai hasil belajar sebaik mungkin [5]. Seseorang yang belajar dengan motivasi tinggi akan melaksanakan kegiatan belajarnya dengan sungguh-sungguh, penuh semangat dan gairah. Sebaliknya siswa yang belajar dengan motivasi rendah akan menjadi malas bahkan tidak mau mengerjakan tugas-tugas yang berhubungan dengan pelajaran.

Hasil penelitian menunjukkan bahwa ada hubungan yang signifikan antara $e$-learning dan motivasi mahasiswa. Jika mahasiswa lebih termotivasi untuk belajar, maka mereka lebih mungkin untuk engaged; dan jika mereka sudah berhasil engage dengan e-learning yang diterapkan oleh kampusnya, maka mereka lebih mungkin untuk mencapai tujuan pembelajaran [4]. Selain itu, hasil penelitian menunjukkan bahwa ada pengaruh yang signifikan antara kuliah online dan minat belajar mahasiswa [1]. Selanjutnya hasil penelitian juga menunjukkan bahwa sekitar 92\% [6] dan 94\% [7] mahasiswa lebih memilih dan lebih suka kuliah tatap muka dari pada kuliah online. Oleh sebab itu, dalam penelitian ini, peneliti tergelitik untuk meneliti tentang "Pengaruh Kuliah Online Terhadap Motivasi Belajar Mahasiswa Pada Perguruan Tinggi Di Daerah Jabodetabek Selama Masa Pandemik Covid-19".

\section{Metode Penelitian}

Jenis penelitian yang digunakan dalam penelitian ini adalah penelitian kausal dengan pendekatan kuantitatif. Penelitian kausal adalah penelitian yang meneliti hubungan sebab-akibat dari suatu fenomena untuk mengukur besarnya hubungan antara dua variabel atau lebih [8]. Penelitian ini didasarkan pada pengujian hipotesis (hypothesis testing) sehingga disebut dengan penelitian kausal, dan menurut sudut pandang waktu penelitian ini termasuk penelitian crosssectional [9]. Penelitian cross sectional adalah penelitian yang dilakukan dengan pengambilan data pada satu waktu dengan subjek yang berbeda untuk menggambarkan keadaan [10]. Lokasi dalam penelitian ini adalah perguruan tinggi-perguruan tinggi yang berada di daerah Jabodetabek (Jakarta-Bogor-Depok-Tangerang-Bekasi). Sedangkan subjek penelitiannya adalah mahasiswa-mahasiswi yang mengikuti perkuliahan online selama masa pandemik covid-19. Penelitian ini dilakukan pada Juli 2020. Populasi dalam penelitian ini adalah seluruh mahasiswa-mahasiswi yang kuliah pada perguruan tinggi di daerah Jabodetabek. Dalam penelitian ini metode pengambilan sampel yang digunakan adalah sampling non probabilitas yaitu semua elemen dalam populasi tidak memiliki kesempatan yang sama untuk dipilih menjadi sampel dan dalam teknik pengambilan sampelnya menggunakan teknik purposive sampling yaitu sampel yang memiliki tujuan untuk memahami informasi tertentu pada sumber tertentu [9]. Karena dalam penelitian ini, peneliti ingin mengetahui sejauhmana motivasi belajar mahasiswa di dalam mengikuti perkuliahan online selama masa pandemik covid-19 ini dan karena populasi dalam penelitian ini juga tidak diketahui maka ukuran sampel adalah 5-10 kali jumlah variabel manifest (indikator) dari keseluruhan variabel laten [11]. Karena dalam penelitian ini jumlah indikator seluruhnya adalah 20 maka jumlah sampel yang digunakan dalam penelitian ini adalah $20 \times 10=200$. Metode pengumpulan data yang digunakan dalam penelitian ini adalah teknik angket melalui google form yakni merupakan metode pengumpulan data yang dilakukan dengan cara membagi daftar pertanyaan kepada responden agar responden tersebut memberikan jawaban dan skala pengukuran yang digunakan dalam penelitian ini adalah skala likert [10]. Jawaban setiap instrumen mempunyai gradasi dari sangat positif sampai dengan negatif, dimana setiap item diberi pilihan respons yang sifatnya tertutup. Untuk mengukur penerapan kuliah online terhadap motivasi belajar mahasiswa pada perguruan tinggi di daerah Jabodetabek maka peneliti menggunakan tipe skala likert berikut ini: Sangat Tidak Setuju=1, Tidak Setuju=2, Netral=3, Setuju=4, Sangat Setuju=5.

Analisis data adalah proses mengolah data dan penginterpretasian hasil pengolahan data. Jenis analisis data yang digunakan dalam penelitian ini adalah analisis deskriptif dan analisis kuantitatif. Analisis deskriptif adalah analisis yang menekankan pada pembahasan data-data dan 
subjek penelitian dengan menyajikan data-data secara sistematik dan tidak menyimpulkan hasil penelitian [12]. Tujuan dari analisis deskriptif ini adalah untuk menganalisis data yang berhubungan dengan karakteristik responden yang meliputi jenis kelamin, usia dan analisis deskriptif terhadap variabel penelitian. Untuk mendeskripsikan penilaian responden terhadap variabel-variabel penelitian yang digunakan perlu dilakukan penentuan distribusi frekuensi berdasarkan nilai intervalnya dengan menggunakan nilai skor, nilai maksimal sebesar 5 dan minimal 1 , rumusnya adalah sebagai berikut [13]:

$$
\begin{aligned}
& \text { Nilai Interval }=\frac{(\text { Nilai batas tertinggi }- \text { Nilai batas terendah) }}{\text { Jumlah Kelas }} \\
& \text { Nilai Interval }=\frac{5-1}{5}=0,8
\end{aligned}
$$

Berdasarkan hasil interval range di atas, maka diperoleh rata-rata skor pada setiap variabel penelitian adalah sebagai berikut:

Tabel 1 Kriteria Skor Variabel Penelitian

\begin{tabular}{|l|l|l|}
\hline Nilai Skor & Kuliah Online & Motivasi Belajar Mahasiswa \\
\hline $1,00-1,80$ & Sangat rendah & Sangat rendah \\
\hline $1,81-2,60$ & Rendah & Rendah \\
\hline $2,61-3,40$ & Sedang & Sedang \\
\hline $3,41-4,20$ & Tinggi & Tinggi \\
\hline $4,21-5,00$ & Sangat tinggi & Sangat tinggi \\
\hline
\end{tabular}

Kriteria pengukuran skor variabel penelitian tersebut menunjukkan bahwa responden yang memilih setuju atau sangat setuju menunjukan tinggi nilai rata-rata yang diperoleh semakin baik terhadap indikator pada variabel penelitian yang digunakan, sedangkan responden yang memilih netral, tidak setuju, dan sangat tidak setuju menunjukkan kecilnya nilai rata-rata yang diperoleh terhadap indikator variabel penelitian yang digunakan.

Sedangkan analisis kuantitatif merupakan analisis yang digunakan untuk data-data yang berbentuk angka yang dapat diukur atau dihitung. Tujuan analisis kuantitatif dalam penelitian ini adalah untuk mengetahui seberapa besar pengaruh variabel independen terhadap variabel dependen. Dalam penelitian ini, peneliti menggunakan analisis regresi linear sederhana karena dalam penelitian ini variabel dependen dipengaruhi hanya oleh satu variabel independen [9]. Persamaan matematis untuk regresi linear sederhana adalah $\mathrm{Y}=\mathrm{a}+\beta \mathrm{X}+\mathcal{E}$.

Keterangan:

$$
\begin{array}{ll}
\mathrm{Y} & \text { : Penaksiran Variabel Dependen } \\
\mathrm{a} & \text { : Nilai Konstanta } \\
\beta & \text { : Koefisien Regresi Dari Kuliah Online } \\
\mathrm{X} & : \text { Kuliah Online } \\
\mathcal{E} & : \text { error }
\end{array}
$$

Untuk mengetahui serta menentukan arah besarnya koefisien antara variabel independen dengan variabel dependen, maka digunakan teknik bantuan SPSS versi 25.0 for windows.

\section{Hasil dan Pembahasan}

Dalam penelitian ini, peneliti menyebarkan angket berupa google form kepada 200 orang responden, namun yang memenuhi kriteria hanya 189 orang responden. Selanjutnya peneliti melakukan analisis secara deskriptif maupun inferensial sebagaimana diuraikan di bawah ini.

a. Hasil Analisis Deskriptif Untuk Profile Responden

Karakteristik responden berdasarkan jenis kelamin dapat dilihat hasilnya pada Tabel 2 di bawah ini:

Tabel 2 Karakteristik Responden Berdasarkan Jenis Kelamin

\begin{tabular}{|c|l|c|c|}
\hline No & \multicolumn{1}{|c|}{ Jenis Kelamin } & Frequency & Percent \\
\hline 1 & Pria & 71 & $37.6 \%$ \\
\hline 2 & Wanita & 118 & $62.4 \%$ \\
\hline & Total & 189 & $100.0 \%$ \\
\hline
\end{tabular}


Sumber: Data Primer Diolah Tahun 2020.

Berdasarkan Tabel 2 di atas menunjukkan bahwa responden yang berjenis kelamin lakilaki dalam penelitian ini sebanyak 71 orang $(37,6 \%)$, sedangkan responden yang berjenis kelamin perempuan dalam penelitian ini sebanyak 118 orang $(62,4 \%)$. Hasil tersebut menunjukkan bahwa mayoritas responden dalam penelitian ini adalah responden yang berjenis kelamin perempuan.

Karakteristik responden berdasarkan usia dapat dilihat hasilnya pada Tabel 3 di bawah ini:

Tabel 3 Karakteristik Responden Berdasarkan Usia

\begin{tabular}{|c|l|c|c|}
\hline No & \multicolumn{1}{|c|}{ Usia } & Frequency & Percent \\
\hline 1 & $\leq 20$ Tahun & 30 & $15.9 \%$ \\
\hline 2 & $21-30$ Tahun & 118 & $62.4 \%$ \\
\hline 3 & $31-40$ Tahun & 31 & $16.4 \%$ \\
\hline 4 & $>40$ Tahun & 10 & $5.3 \%$ \\
\hline & Total & 189 & $100.0 \%$ \\
\hline
\end{tabular}

Sumber: Data Primer Diolah Tahun 2020.

Berdasarkan Tabel 3 di atas menunjukkan bahwa responden yang berusia $\leq 20$ tahun sebanyak 30 orang (15,9\%), responden yang berusia antara 21-30 tahun sebanyak 118 orang $(62,4 \%)$, responden yang berusia antara 31-40 tahun sebanyak 31 orang $(16,4 \%)$, sedangkan responden yang berusia di atas 40 tahun sebanyak $10(5,3 \%)$. Hasil tersebut menunjukkan bahwa mayoritas responden dalam penelitian ini adalah responden yang berusia antara 21-30 tahun.

Karakteristik responden berdasarkan lokasi kampus dapat dilihat hasilnya pada Tabel 4 di bawah ini:

Tabel 4 Karakteristik Responden Berdasarkan Lokasi Kampus

\begin{tabular}{|c|l|c|c|}
\hline No & \multicolumn{1}{|c|}{ Lokasi Kampus } & Frequency & Percent \\
\hline 1 & Bogor & 2 & $1.1 \%$ \\
\hline 2 & Depok & 2 & $1.1 \%$ \\
\hline 3 & Tangerang & 49 & $25.9 \%$ \\
\hline 4 & Jakarta & 136 & $72.0 \%$ \\
\hline & Total & 189 & $100.0 \%$ \\
\hline
\end{tabular}

Sumber: Data Primer Diolah Tahun 2020.

Berdasarkan Tabel 4 di atas menunjukkan bahwa responden yang digunakan dalam penelitian ini berasal dari berbagai perguruan tinggi yang menyebar di 4 lokasi yaitu Bogor, Depok, Tangerang dan Jakarta. Hasil analisis di atas menunjukkan 2 mahasiswa $(1,1 \%)$ berasal dari perguruan tinggi yang berlokasi di Bogor, 2 mahasiswa $(1,1 \%)$ berasal dari perguruan tinggi yang berlokasi di Depok, 49 mahasiswa $(25,9 \%)$ berasal dari perguruan tinggi yang berlokasi di Tangerang dan yang paling banyak adalah mahasiswa yang berasal dari perguruan tinggi di Kota Jakarta yaitu sebanyak 136 mahasiswa (72,0\%).

Karakteristik responden berdasarkan jenjang pendidikan dapat dilihat hasilnya pada Tabel 5 di bawah ini:

Tabel 5 Karakteristik Responden Berdasarkan Jenjang Pendidikan

\begin{tabular}{|c|l|c|c|}
\hline No & Jenjang Pendidikan & Frequency & Percent \\
\hline 1 & D3 & 6 & $3.2 \%$ \\
\hline 2 & D4 & 3 & $1.6 \%$ \\
\hline 3 & S1 & 113 & $59.8 \%$ \\
\hline 4 & S2 & 63 & $33.3 \%$ \\
\hline 5 & S3 & 4 & $2.1 \%$ \\
\hline & Total & 189 & $100.0 \%$ \\
\hline
\end{tabular}

Sumber: Data Primer Diolah Tahun 2020. 
Berdasarkan Tabel 5 di atas menunjukkan bahwa responden yang saat ini sedang menempuh jenjang pendidikan D3 sebanyak 6 mahasiswa $(3,2 \%)$, responden yang sedang menempuh jenjang pendidikan D4 sebanyak 3 mahasiswa $(1,6 \%)$, responden yang sedang menempuh jenjang pendidikan S1 sebanyak 113 mahasiswa $(59,8 \%)$, responden yang sedang menempuh jenjang pendidikan S2 sebanyak 63 mahasiswa $(33,3 \%)$, dan responden yang sedang menempuh jenjang pendidikan S3 sebanyak 4 mahasiswa $(2,1 \%)$. Hasil tersebut menunjukkan bahwa mayoritas responden dalam penelitian ini adalah responden yang sedang menempuh jenjang pendidikan S1.

b. Hasil Analisis Deskriptif Untuk Variabel Penelitian

Adapun hasil analisis deskriptif untuk variabel kuliah online (X) adalah sebagai berikut:

Tabel 6 Variabel Kuliah Online

\begin{tabular}{|c|c|c|c|c|c|c|c|}
\hline No & Variabel Kuliah Online (X) & $\begin{array}{l}\text { Sangat } \\
\text { Tidak } \\
\text { Setuju } \\
\text { (1) }\end{array}$ & $\begin{array}{l}\text { Tidak } \\
\text { Setuju } \\
\text { (2) }\end{array}$ & $\begin{array}{c}\text { Netral } \\
\text { (3) }\end{array}$ & $\begin{array}{l}\text { Setuju } \\
\text { (4) }\end{array}$ & $\begin{array}{l}\text { Sangat } \\
\text { Setuju } \\
(5)\end{array}$ & $\begin{array}{l}\text { Nilai } \\
\text { Mean }\end{array}$ \\
\hline 1. & $\begin{array}{l}\text { Kuliah online lebih memberi kemudahan } \\
\text { bagi saya karena tidak dibatasi lagi oleh } \\
\text { ruang dan waktu. }\end{array}$ & 14 & 14 & 39 & 57 & 65 & 3.77 \\
\hline 2. & $\begin{array}{l}\text { Melalui kuliah online, komunikasi antara } \\
\text { dosen dan mahasiswa dapat terjadi setiap } \\
\text { saat. }\end{array}$ & 15 & 34 & 39 & 60 & 41 & 3.41 \\
\hline 3. & $\begin{array}{l}\text { Kuliah online melatih mahasiswa untuk } \\
\text { dapat belajar secara mandiri dengan } \\
\text { memanfaatkan materi kuliah yang } \\
\text { diberikan secara online. }\end{array}$ & 10 & 8 & 30 & 65 & 76 & 4.00 \\
\hline 4. & $\begin{array}{l}\text { Kuliah online melatih mahasiswa untuk } \\
\text { terbiasa menggunakan sumber-sumber } \\
\text { belajar dari internet. }\end{array}$ & 3 & 5 & 20 & 67 & 94 & 4.29 \\
\hline 5. & $\begin{array}{l}\text { Kuliah online dapat meningkatkan } \\
\text { keterampilan mahasiswa dalam } \\
\text { menggunakan komputer beserta } \\
\text { perangkat lainnya. }\end{array}$ & 4 & 10 & 7 & 73 & 95 & 4.30 \\
\hline 6. & $\begin{array}{l}\text { Mahasiswa dapat mengakses materi } \\
\text { perkuliahan dimana saja dan kapan saja } \\
\text { tanpa harus bergantung pada jadwal. }\end{array}$ & 4 & 17 & 26 & 58 & 84 & 4.06 \\
\hline 7 & $\begin{array}{l}\text { Miskomunikasi sesama mahasiswa lebih } \\
\text { sering terjadi dalam perkuliahan online, } \\
\text { seperti membuat makalah. }\end{array}$ & 11 & 29 & 35 & 57 & 57 & 3.63 \\
\hline 8 & $\begin{array}{l}\text { Berkolaborasi dengan sesama mahasiswa } \\
\text { seperti membuat penelitian bersama dan } \\
\text { makalah lebih sering terjadi dalam } \\
\text { perkuliahan online. }\end{array}$ & 15 & 38 & 35 & 59 & 42 & 3.40 \\
\hline 9 & $\begin{array}{l}\text { Menyelesaikan permasalahan sesama } \\
\text { mahasiswa lebih mudah dalam } \\
\text { pembelajaran online, seperti makalah } \\
\text { kelompok yang belum lengkap. }\end{array}$ & 20 & 44 & 47 & 40 & 38 & 3.17 \\
\hline 10 & $\begin{array}{l}\text { Kuliah online selama ini dapat berjalan } \\
\text { dengan baik dan efektif. }\end{array}$ & 19 & 37 & 48 & 53 & 32 & 3.22 \\
\hline \multicolumn{7}{|c|}{ Nilai mean untuk variabel Kuliah Online (X) } & 3.73 \\
\hline
\end{tabular}

Sumber: Data Primer Diolah Tahun 2020.

Nilai mean untuk variabel kuliah online di atas jika dirata-ratakan diperoleh nilai sebesar 3.73. Nilai ini termasuk tinggi karena sebagian besar mahasiswa menjawab setuju bahwa dengan adanya kuliah online di masa pandemi covid-19 ini sangat efektif untuk diterapkan oleh setiap kampus karena dengan adanya kuliah online walaupun mahasiswa dan dosen tidak bertemu secara langsung (tatap muka), namun kegiatan belajar mengajarnya bisa terlaksana dengan baik. Sedangkan nilai mean tertinggi penilaian responden pada variabel kuliah online adalah pada pertanyaan nomor ke- 5 dengan nilai meannya sebesar 4.30 yang menyatakan bahwa dengan adanya kuliah online dapat meningkatkan keterampilan mahasiswa dalam menggunakan 
komputer beserta perangkat lainnya. Sedangkan skor rata-rata terendah pada variabel kuliah online adalah pada pertanyaan nomor ke-9 dengan nilai mean sebesar 3.17 yang menyatakan bahwa dengan adanya kuliah online dapat menyelesaikan permasalahan sesama mahasiswa lebih mudah, seperti makalah kelompok yang belum lengkap. Berdasarkan hasil analisis tersebut, setiap perguruan tinggi di daerah Jabodetabek, perlu mengkaji kembali perkuliahan online yang sudah diterapkan selama ini agar kedepannya layanan kuliah online yang diberikan kepada mahasiswa dapat memotivasi mereka untuk terus meningkatkan kemampuan belajar mereka.

Untuk variabel motivasi belajar mahasiswa (Y) dapat dilihat hasil analisis deskriptifnya di bawah ini:

Tabel 7 Variabel Motivasi Belajar Mahasiswa

\begin{tabular}{|c|c|c|c|c|c|c|c|}
\hline No & Variabel Motivasi Belajar Mahasiswa (Y) & $\begin{array}{l}\text { Sangat } \\
\text { Tidak } \\
\text { Setuju } \\
\text { (1) }\end{array}$ & $\begin{array}{l}\text { Tidak } \\
\text { Setuju } \\
\text { (2) }\end{array}$ & $\begin{array}{c}\text { Netral } \\
\text { (3) }\end{array}$ & $\begin{array}{l}\text { Setuju } \\
\text { (4) }\end{array}$ & $\begin{array}{l}\text { Sangat } \\
\text { Setuju } \\
\text { (5) }\end{array}$ & $\begin{array}{l}\text { Nilai } \\
\text { Mean }\end{array}$ \\
\hline 1 & $\begin{array}{l}\text { Saya lebih senang kuliah online dari pada } \\
\text { tatap muka, karena kuliah online dapat } \\
\text { dilakukan dimana saja dan kapan saja. }\end{array}$ & 45 & 35 & 35 & 31 & 43 & 2.96 \\
\hline 2 & $\begin{array}{l}\text { Kuliah online membuat saya lebih } \\
\text { semangat dan lebih giat belajar untuk } \\
\text { memahami materi kuliah yang diberikan } \\
\text { oleh dosen. }\end{array}$ & 37 & 43 & 46 & 37 & 26 & 2.85 \\
\hline 3 & $\begin{array}{l}\text { Kuliah online mendorong saya untuk } \\
\text { meningkatkan kemampuan dan potensi } \\
\text { yang saya miliki. }\end{array}$ & 15 & 32 & 46 & 44 & 52 & 3.46 \\
\hline 4 & $\begin{array}{l}\text { Saya merasa nyaman untuk menjawab } \\
\text { pertanyaan-pertanyaan yang diberikan } \\
\text { oleh dosen dalam perkuliahan online. }\end{array}$ & 11 & 30 & 55 & 46 & 47 & 3.47 \\
\hline 5 & $\begin{array}{l}\text { Kuliah online membuat saya lebih mudah } \\
\text { menemukan kebutuhan belajar saya. }\end{array}$ & 15 & 33 & 55 & 46 & 40 & 3.33 \\
\hline 6 & $\begin{array}{l}\text { Kuliah online membuat saya semakin } \\
\text { berusaha dan tekun untuk mencapai hasil } \\
\text { belajar yang sebaik mungkin. }\end{array}$ & 9 & 27 & 41 & 63 & 49 & 3.61 \\
\hline 7 & $\begin{array}{l}\text { Melalui kuliah online, saya memiliki } \\
\text { motivasi yang tinggi untuk belajar } \\
\text { dengan sungguh-sungguh. }\end{array}$ & 19 & 25 & 49 & 53 & 43 & 3.40 \\
\hline 8 & $\begin{array}{l}\text { Selama pelaksanaan kuliah online, saya } \\
\text { rajin mengerjakan tugas dan submit tugas } \\
\text { tepat waktu. }\end{array}$ & 8 & 16 & 46 & 59 & 60 & 3.78 \\
\hline 9 & $\begin{array}{l}\text { Saya sangat senang karena melalui kuliah } \\
\text { online saya memperoleh hasil yang } \\
\text { sangat memuaskan. }\end{array}$ & 16 & 20 & 50 & 59 & 44 & 3.50 \\
\hline 10 & $\begin{array}{l}\text { Saya menyarankan agar perkuliahan } \\
\text { kedepannya diadakan dalam bentuk } \\
\text { online karena tidak dibatasi lagi oleh } \\
\text { ruang dan waktu. }\end{array}$ & 50 & 27 & 33 & 42 & 37 & 2.94 \\
\hline \multicolumn{7}{|c|}{ Nilai Mean untuk variabel Motivasi Belajar Mahasiswa (Y) } & 3.33 \\
\hline
\end{tabular}

Sumber: Data Primer Diolah Tahun 2020.

Nilai mean untuk variabel motivasi belajar mahasiswa di atas jika dirata-ratakan diperoleh nilai sebesar 3.33. Nilai ini termasuk sedang karena sebagian besar mahasiswa menjawab tidak setuju. Hal ini menunjukkan bahwa sebagian besar mahasiswa tidak senang kuliah online yang diterapkan oleh pihak kampus selama masa pandemi covid-19 ini, tentunya ini mengindikasikan bahwa mahasiswa sudah terbiasa dengan perkuliahan tatap muka dengan dosen sehingga saat terjadi pandemi covid-19 dan setiap kampus mengadakan perkuliahan online, mahasiswa memiliki motivasi yang rendah. Hal ini dapat dilihat pada penilaian responden pada pernyataan pertama, kedua dan kesepuluh bahwa sebagian besar mahasiswa 
tidak senang dengan adanya kuliah online, karena kuliah online justru membuat mereka tidak memiliki semangat untuk belajar, mereka lebih suka kuliah tatap muka daripada kuliah online, sehingga mereka menyarankan agar setelah pandemi covid-19 ini berlalu, kuliah tatap muka segera dibuka kembali oleh pihak kampus. Walaupun demikian, sebagian besar mahasiswa justru memiliki minat dan usaha yang tinggi untuk mencapai hasil yang maksimal selama perkuliahan online ini. Hal ini dapat dilihat dari penilaian responden pada pertanyaan nomor keenam dan kedelapan bahwa kuliah online membuat mereka semakin berusaha dan tekun belajar, rajin mengerjakan tugas dan menyerahkan tugas tepat waktu, artinya mereka berusaha untuk mencapai hasil belajar yang sebaik mungkin selama pelaksanaan kuliah online ini.

c. Model Regresi Linear Sederhana

Dalam penelitian ini, dilakukan analisis regresi linear sederhana untuk mencari pengaruh kuliah online terhadap motivasi belajar mahasiswa pada masa pandemic covid-19 ini.

Tabel 8 Hasil Analisis Regresi Linier Sederhana

\begin{tabular}{|c|c|c|c|c|c|c|}
\hline \multicolumn{7}{|c|}{ Coefficients $^{a}$} \\
\hline \multirow{2}{*}{\multicolumn{2}{|c|}{ Model }} & \multicolumn{2}{|c|}{ Unstandardized Coefficients } & \multirow{2}{*}{$\begin{array}{c}\text { Standardized } \\
\text { Coefficients } \\
\text { Beta }\end{array}$} & \multirow[b]{2}{*}{$\mathrm{t}$} & \multirow[b]{2}{*}{ Sig. } \\
\hline & & $\mathrm{B}$ & Std. Error & & & \\
\hline 1 & (Constant) & -5.857 & 2.529 & & -2.316 & .022 \\
\hline & Kuliah Online (X) & 1.051 & .067 & .756 & 15.787 & .000 \\
\hline
\end{tabular}

\section{Sumber: Data Primer Diolah Tahun 2020.}

Adapun persamaan regresi linear sederhana dalam penelitian ini adalah $Y=a+\beta X$ menjadi $\mathrm{Y}=-5.857+1.051 \mathrm{X}$. Berdasarkan persamaan tersebut dapat dijabarkan sebagai berikut:

Nilai konstanta sebesar (-5.857) menunjukkan bahwa besarnya nilai motivasi belajar mahasiswa (Y) diprediksi sebesar (-5.857) tanpa dipengaruhi oleh variabel kuliah online (X). Nilai signifikansinya $0.22<0,05$ maka nilai konstanta (a) signifikan untuk menjadi prediksi nilai motivasi belajar mahasiswa $(\mathrm{Y})$.

Pada variabel kuliah online (X) mempunyai koefisien regresi yang positif terhadap nilai motivasi belajar mahasiswa (Y) pada perguruan tinggi di daerah Jabodetabek, dengan koefisien regresi sebesar 1.051, artinya setiap adanya kenaikan satu satuan variabel kuliah online (X) akan meningkatkan motivasi belajar mahasiswa (Y) pada perguruan tinggi di daerah Jabodetabek sebesar 1.051 dengan asumsi variabel yang lainnya adalah konstan. Dan nilai signifikansinya sebesar $0,00<0,05$ maka nilai koefisien regresi variabel kuliah online $(\mathrm{X})$ signifikan untuk menjadi prediksi nilai motivasi belajar mahasiswa $(Y)$.

d. Uji Koefisien Determinasi $\left(R^{2}\right)$

Adapun hasil uji koefisien determinasi $\left(R^{2}\right)$ dalam penelitian ini adalah sebagai berikut: Tabel 9 Hasil Uji Determinasi $\left(\mathrm{R}^{2}\right)$

\begin{tabular}{|c|c|c|c|c|}
\hline Model & $\mathrm{R}$ & R Square & Adjusted R Square & Std. Error of the Estimate \\
\hline 1 & $.756^{\mathrm{a}}$ & .571 & .569 & 6.78918 \\
\hline
\end{tabular}

a. Predictors: (Constant), Kuliah Online (X)

b. Dependent Variable: Motivasi Belajar (Y)

Sumber: Data Primer Diolah Tahun 2020.

Dari hasil pengujian di atas diperoleh nilai koefisien determinasi sebesar 0.571. Jadi sumbangan pengaruh kuliah online (X) terhadap motivasi belajar mahasiswa (Y) pada pada perguruan tinggi di daerah Jabodetabek adalah sebesar 57.1\%, sedangkan sisanya (100\% $57.1 \%=42.9 \%$ ) dipengaruhi oleh faktor lain.

e. Pengujian Hipotesis Kuliah Online (X) Terhadap Motivasi Belajar Mahasiswa (Y)

Untuk melakukan pengujian hipotesis dengan menggunakan uji $t$, dengan membandingkan nilai $t_{\text {hitung }}$ dengan nilai $t_{\text {tabel}}$, jika memiliki nilai $t_{\text {hitung }}>$ nilai $t_{\text {tabel }}$ maka dinyatakan ada pengaruh dari variabel kuliah online $(\mathrm{X})$ terhadap motivasi belajar mahasiswa (Y) pada perguruan tinggi di daerah Jabodetabek dan sebaliknya jika memiliki nilai $t_{\text {hitung }} \leq$ nilai $\mathrm{t}_{\text {tabel }}$ maka dinyatakan tidak ada pengaruh dari variabel kuliah online $(\mathrm{X})$ terhadap motivasi belajar mahasiswa (Y) pada perguruan tinggi di daerah Jabodetabek. 
Berdasarkan pada Tabel 10 di bawah ini menunjukkan bahwa dapat diketahui apakah akan menerima hipotesis ataukah menolak hipotesis.

Tabel 10 Hasil Uji Parsial (Uji t)

\begin{tabular}{|c|c|c|c|c|c|c|}
\hline \multicolumn{7}{|c|}{ Coefficients $^{a}$} \\
\hline \multirow{2}{*}{\multicolumn{2}{|c|}{ Model }} & \multicolumn{2}{|c|}{ Unstandardized Coefficients } & \multirow{2}{*}{$\begin{array}{c}\begin{array}{c}\text { Standardized } \\
\text { Coefficients }\end{array} \\
\text { Beta }\end{array}$} & \multirow[b]{2}{*}{$\mathrm{t}$} & \multirow[b]{2}{*}{ Sig. } \\
\hline & & $\mathrm{B}$ & Std. Error & & & \\
\hline 1 & (Constant) & -5.857 & 2.529 & & -2.316 & .022 \\
\hline & Kuliah Online (X) & 1.051 & .067 & .756 & 15.787 & .000 \\
\hline
\end{tabular}

a. Dependent Variable: Motivasi Belajar (Y)

Sumber: Data Primer Diolah Tahun 2020.

Berdasarkan Tabel 10 di atas, tahapan untuk pengujian uji $\mathrm{t}$ adalah dengan cara menentukan $\mathrm{H}_{0}$ dan $\mathrm{H}_{\mathrm{a}}$ :

$\mathrm{H}_{0}: \beta=0$. Artinya kuliah online (X) tidak berpengaruh terhadap motivasi belajar mahasiswa (Y) pada perguruan tinggi di daerah Jabodetabek.

$\mathrm{H}_{\mathrm{a}}: \beta \neq 0$. Artinya kuliah online $(\mathrm{X})$ berpengaruh terhadap motivasi belajar mahasiswa $(\mathrm{Y})$ pada perguruan tinggi di daerah Jabodetabek.

Selanjutnya menentukan taraf signifikansi yaitu dalam penelitian ini menggunakan taraf signifikansi $(\alpha)=0,05$. Sedangkan untuk menentukan nilai $t_{\text {tabel }}$ dapat diperoleh dari derajat kebebasan yaitu $\mathrm{df}=\mathrm{n}-2$ atau $189-2=187, \alpha=0,05$. Karena merupakan uji 2 sisi maka $\alpha / 2=$ $0,05 / 2=0,025$ sehingga $t_{\text {tabel }}=1.973$. Dan untuk pengambilan keputusannya adalah jika $t_{\text {hitung }} \leq$ $\mathrm{t}_{\text {tabel }}$ maka $\mathrm{H}_{0}$ diterima artinya kuliah online $(\mathrm{X})$ tidak berpengaruh terhadap motivasi belajar mahasiswa (Y) pada perguruan tinggi di daerah Jabodetabek. Jika $t_{\text {hitung }}>t_{\text {tabel }}$ maka $H_{0}$ ditolak artinya kuliah online $(\mathrm{X})$ berpengaruh terhadap motivasi belajar mahasiswa $(\mathrm{Y})$ pada perguruan tinggi di daerah Jabodetabek.

Dalam penelitian ini diperoleh nilai $t_{\text {hitung }}$ sebesar (15.787) $>t_{\text {tabel }}$ (1.973). Jadi $\mathrm{H}_{0}$ ditolak dan $\mathrm{H}_{\mathrm{a}}$ diterima artinya kuliah online $(\mathrm{X})$ berpengaruh positif terhadap motivasi belajar mahasiswa (Y) pada perguruan tinggi di daerah Jabodetabek, sehingga hipotesis yang menyatakan bahwa ada pengaruh positif kuliah online (X) terhadap motivasi belajar mahasiswa (Y) pada perguruan tinggi di daerah Jabodetabek, terbukti.

f. Pembahasan

Berdasarkan hasil analisis deskriptif variabel penelitian yang dilakukan di atas serta melihat tanggapan dan komentar dari setiap responden yang mengisi kuesioner penelitian ini bahwa pada dasarnya kuliah online tidak seefektif dan seefisien kuliah tatap muka, kuliah online tidak berjalan seoptimal dan semaksimal kuliah tatap muka.

Hal ini karena banyak kendala dan kesulitan yang terjadi dalam kuliah online misalnya mahasiswa harus beradaptasi dengan adannya aplikasi kelas online yang digunakan seperti microsoft teams, zoom, classroom, webex, dll; adanya gangguan jaringan dan device; mati listrik; kurangnya sarana dan prasarana, masalah-masalah teknis ini tentunya diluar kendali mahasiswa.

Kuliah online sesungguhnya memiliki keterbatasan antara para pendidik dan peserta didik, dimana dilihat dari proses pembelajaran yang dilaksanakan masih terdapat kekurangan dalam penyampaian materi. Peserta didik masih kurang memahami secara utuh materi yang disampaikan oleh para pendidik sehingga yang terjadi adalah mahasiswa harus berusaha untuk mencari tahu sendiri, disamping itu juga banyaknya tugas yang diberikan oleh dosen kepada mahasiswa, serta deadline dengan durasi waktu yang cukup cepat.

Kuliah online tentunya memiliki dampak positif dan negatif. Sebagai contoh dampak negatifnya adalah ketika kelas online melalui voice call, banyak mahasiswa/i yang tidak mendengarkan dosen mengajar, mereka justru melakukan berbagai aktivitas lainnya diluar 
konteks pelajaran. Adanya distorsi komunikasi, seperti terdengar suara kendaraan lalu lalang, suara yang putus-putus akibat signal internet yang kurang baik, membuat komunikasi antar dosen dengan mahasiswa terganggu selama kelas berlangsung. Selain itu juga, kelas online melalui voice call tidak bisa melihat wajah maupun ekspresi lawan bicara, maka dosen maupun mahasiswa sering terjadi kesalahpahaman dalam berkomunikasi. Sedangkan dampak positifnya adalah efisien waktu dan tenaga yaitu tidak dibatasi lagi oleh ruang dan waktu, perkuliahan dapat dilakukan dimana saja dan kapan saja.

Mahasiswa tentunya, lebih memilih kuliah tatap muka dari pada kuliah online karena selain perkuliahan dapat berjalan optimal dan efektif, disamping itu juga dapat membangun hubungan sosial antara dosen dengan mahasiswa, mahasiswa dengan mahasiswa, dan dosen dengan dosen serta para staf atau pegawai yang ada di kampus. Kuliah tatap muka mahasiswa lebih fokus dan lebih semangat belajar karena mahasiswa dapat bertemu langsung dengan dosennya dan juga teman-temannya. Suasana belajarnya tentunya lebih nyaman dan menyenangkan.

Terlepas dari hasil analisis deskriptif dan tanggapan dan komentar yang diberikan oleh para responden. Peneliti juga melakukan analisisi inferensial untuk mencari tahu pengaruh variabel kuliah online terhadap motivasi belajar mahasiswa pada perguruan tinggi di daerah Jabodetabek. Berdasarkan hasil analisis yang dilakukan, hasil penelitian menunjukkan bahwa ada pengaruh positif dan signifikan dari variabel kuliah online terhadap motivasi belajar mahasiswa karena dapat diketahui bahwa $t_{\text {hitung }}(15.787)>t_{\text {tabel }}(1.973)$ dan nilai signifikansinya $0,00<0,05$. Jadi $\mathrm{H}_{0}$ ditolak dan $\mathrm{H}_{\mathrm{a}}$ diterima artinya kuliah online $(\mathrm{X})$ berpengaruh positif dan signifikan terhadap motivasi belajar mahasiswa (Y) pada perguruan tinggi di daerah Jabodetabek.

Berdasarkan pembahasan hasil analisis di atas maka kuliah online cenderung membuat mahasiswa jenuh, bosan, serta tingkat motivasi dan minat belajarnya menjadi rendah. Hal ini tentunya wajar bagi mahasiswa dan dosen karena kuliah online yang diterapkan oleh pihak kampus, itu bukan merupakan keinginan mereka tetapi dipaksa oleh situasi pandemi covid-19 sehingga mau tidak mau, setiap kampus khususnya di daerah Jabodetabek wajib menerapkan kuliah online. Mengingat daerah Jabodetabek ini merupakan daerah zona merah pandemi covid19.

\section{Kesimpulan}

Berdasarkan hasil temuan dan pembahasan di atas tentang pengaruh kuliah online terhadap motivasi belajar mahasiswa pada perguruan tinggi di daerah Jabodetabek maka dapat ditarik kesimpulannya adalah sebagai berikut:

Berdasarkan hasil analisis deskriptif variabel penelitian yang dilakukan di atas serta melihat tanggapan dan komentar dari setiap responden yang mengisi kuesioner penelitian bahwa pada dasarnya kuliah online tidak seefektif dan seefisien kuliah tatap muka, kuliah online tidak berjalan seoptimal dan semaksimal kuliah tatap muka.

Dapat diketahui bahwa $t_{\text {hitung }}(15.787)>t_{\text {tabel }}$ (1.973). Jadi $\mathrm{H}_{0}$ ditolak dan $\mathrm{H}_{\mathrm{a}}$ diterima artinya kuliah online $(\mathrm{X})$ berpengaruh positif terhadap motivasi belajar mahasiswa (Y) pada perguruan tinggi di daerah Jabodetabek, sehingga hipotesis yang menyatakan bahwa ada pengaruh positif kuliah online $(\mathrm{X})$ terhadap motivasi belajar mahasiswa $(\mathrm{Y})$ pada perguruan tinggi di daerah Jabodetabek, terbukti. Dan sumbangan pengaruh kuliah online (X) terhadap motivasi belajar mahasiswa (Y) pada pada perguruan tinggi di daerah Jabodetabek adalah sebesar $57.1 \%$.

Dari hasil temuan dalam penelitian ini, walaupun banyak responden yang tidak menginginkan kuliah online namun terdapat responden yang menyarankan agar ketika pandemik covid-19 ini berlalu, metode perkuliahan secara online, tetap diberlakukan di setiap kampus khususnya untuk program kelas karyawan. Dengan pertimbangan bahwa pada umumnya orang-orang yang sudah bekerja hanya sedikit memiliki waktu untuk bermobilisasi (kantor-kampus-rumah/kos). Oleh sebab itu, perlu diadakan kampus merdeka belajar yakni dapat belajar di mana saja dan kapan saja. Karena dengan adanya metode perkuliahan secara 
online dapat memacu mahasiswa untuk dapat menyerap materi secara maksimal dan mengerjakan setiap tugas dengan jauh lebih baik dibanding saat perkuliahan offline.

\section{Daftar Pustaka}

[1] H. N. Z.R and W. Saugi, "Pengaruh Kuliah Online Terhadap Minat Belajar Mahasiswa Pendidikan Agama Islam (PAI) di IAIN Samarinda," el-Buhuth Borneo J. Islam. Stud., vol. 2, no. 2, pp. 121-131, Jun. 2020, Accessed: Jun. 26, 2020. [Online]. Available: https://journal.iain-samarinda.ac.id/index.php/el-Buhuth/article/view/2330.

[2] A. F. Rahman, "Menkominfo Sebut Indonesia Masih Kekurangan Talenta Digital," Detiknet, Jun. 15, 2020. https://inet.detik.com/cyberlife/d-5054815/menkominfo-sebutindonesia-masih-kekurangan-talenta-digital?_ga=2.77871767.2053534338.15932224501330262597.1585046584 (accessed Jun. 27, 2020).

[3] W. A. Prodjo, "Mendikbud Nadiem Akui Sulitnya Proses Adaptasi Online Learning," 2020.

[4] S. R. Harandi, "Effects of e-learning on Students' Motivation," Procedia - Soc. Behav. Sci., vol. 181, pp. 423-430, 2015, doi: 10.1016/j.sbspro.2015.04.905.

[5] N. Nirfayanti and N. Nurbaeti, "Pengaruh Media Pembelajaran Google Classroom Dalam Pembelajaran Analisis Real Terhadap Motivasi Belajar Mahasiswa," Proximal, vol. 2, no. 1, pp. 50-59, 2019, doi: https://doi.org/10.30605/2615-7667.211.

[6] A. Kusnayat, N. Sumarni, A. S. Mansyur, and Q. Y. Zaqiah, "Pengaruh Teknologi Pembelajaran Kuliah Online Di Era Covid-19 Dan Dampaknya Terhadap Mental Mahasiswa," EduTeach J. Edukasi dan Teknol. Pembelajaran, vol. 1, no. 2, pp. 153$165,2020$.

[7] S. Riadi, E. N. Normelani, M. Efendi, I. Safitri, and G. Firza Ismi Tsabita, "Persepsi Mahasiswa Prodi S1 Geografi FISIP ULM Terhadap Kuliah Online Di Masa Pandemi Covid-19," PADARINGAN (Jurnal Pendidik. Sosiol. Antropol., vol. 2, no. 2, p. 219, 2020, doi: 10.20527/padaringan.v2i2.2151.

[8] B. Setiawan and A. Muntaha, "Unsur-unsur Fundamental Penelitian Sosial," 2014.

[9] T. Wijaya, Metode Penelitian Ekonomi dan Bisnis. Yogyakarta: Graha Ilmu, 2013.

[10] S. Suliyanto, Metode Penelitian Bisnis untuk Skripsi, Tesis, \& Disertasi. Yogyakarta: Andi Offset, 2018.

[11] M. Sofyan, "Pengaruh CSR perusahaan terhadap citra merek dan loyalitas merek," $J$. Siasat Bisnis, vol. 21, no. 1, pp. 1-18, 2017, doi: 10.20885/jsb.vol21.iss1.art1.

[12] D. Priyatno, Mandiri Belajar SPSS (Statistical Product and Service Solution) Untuk AnalisisData \& Uji Statistik. Yogyakarta: MediaKom, 2008.

[13] N. P. D. Ermawati and I. K. Ardana, "Pengaruh Kepemimpinan Transformasional, Budaya Organisasi dan Motivasi Terhadap Komitmen Organisasional Pada BPR Di Kabupaten Klungkung," E-Jurnal Manaj. Univ. Udayana, vol. 7, no. 11, pp. 6326-6359, 2018. 